\title{
Beyond the Bounds of Western Europe: Paleolithic Art in the Balkan Peninsula
}

Aitor Ruiz-Redondo ${ }^{1,2,3^{\star}}$, Diego Garate ${ }^{4}$, Manuel R. González-Morales ${ }^{4}$, Ivor Janković ${ }^{5,6}$, Jacques Jaubert ${ }^{1}$, Ivor Karavanić ${ }^{6,7}$, Darko Komšo ${ }^{8}$, Steven L. Kuhn ${ }^{9}$, Dušan Mihailović ${ }^{10}$, Óscar Moro Abadía ${ }^{11}$, Marc Vander Linden ${ }^{12}$, Nikola Vukosavljević ${ }^{7}$

${ }^{1}$ PACEA (UMR5199), Université de Bordeaux, Bât. B2. allée Geoffroy Saint-Hilaire 33615 Pessac, France

${ }^{2}$ Centre for the Archaeology of Human Origins (CAHO), Department of Archaeology, Faculty of Arts \& Humanities, University of Southampton. Avenue Campus, SO17 1BF Southampton, United Kingdom

${ }^{3}$ Department of Ancient Studies, University of Zaragoza, Corona de Aragón 42, 50009 Zaragoza, Spain

${ }^{4}$ IIIPC-Universidad de Cantabria. Edificio Interfacultativo, Avda. de Los Castros 52, 39005 Santander, Spain

${ }^{5}$ Institute for Anthropological Research, Ljudevita Gaja 32, 1000 Zagreb, Croatia

${ }^{6}$ Department of Anthropology, University of Wyoming, Laramie, WY 82071, USA

${ }^{7}$ Department of Archaeology, University of Zagreb, Ivana Lučića 3, 10000 Zagreb, Croatia

${ }^{8}$ Archaeological Museum of Istria, Carrarina 3, 52100 Pula, Croatia

${ }^{9}$ School of Anthropology, Emil W. Haury Building, 1009 East South Campus Drive, Tucson, AZ 85721, USA

${ }^{10}$ Faculty of Philosophy, University of Belgrade, 18-20 Čika-Ljubina, 11000 Beograd, Serbia

${ }^{11}$ Department of Archaeology, Memorial University of Newfoundland, Queen's College, A1C $5 S 7$ St. John's, Canada

12 Department of Archaeology and Anthropology, Bournemouth University, Talbot Campus, BH125BB Poole, United Kingdom

* Corresponding author (email: aruizredondo@gmail.com ; Tel.: (+34) 679366851 


\begin{abstract}
Paleolithic art offers unique perspectives on prehistoric societies and cultures. It is also considered a key component of modern human behavior. Until recently, Paleolithic artworks were thought to be geographically restricted to a very few areas, especially southwestern Europe. Discoveries of art in other parts of Europe and other parts of the globe have challenged this vision, expanding the documented distribution of this important cultural phenomenon. As a consequence, there has been renewed interest in less well-known areas, with the goal of determining whether the current lack of art is a reflection of a past reality, the product of limited research, or a matter of preservation. One of these regions is the Balkan Peninsula, a key area for understanding Upper Paleolithic societies given its location at the crossroads of several migration routes into Europe. This article provides a comprehensive overview of the Paleolithic symbolic products, including both rock art and portable art from the Balkans. Recent research has led to new discoveries and insights into the symbolism of this long-neglected area. The present review, combining existing literature and new fieldwork, sheds new light on social and cultural interactions in this part of the continent and leads to a better understanding of its role within the European Upper Paleolithic cultural sphere.
\end{abstract}

Keywords. Upper Paleolithic; rock art; portable art; Balkan Peninsula; Southeastern Europe; symbolic behavior. 


\section{Introduction}

The production of art ('imagery') was a major cultural phenomenon for many Paleolithic societies. Archaeologists have traditionally considered its emergence as one of the first expressions of symbolic thought and expression in human history (Mellars 1989; Mithen 1996; d'Errico 2003). In the fields of archaeology and paleoanthropology, production of images by Paleolithic peoples is considered one of the archaeological signatures of modern human behavior (d'Errico 2003; Mellars 2005; Zilhão 2007) and one of the major innovations of the 'Upper Paleolithic Revolution' (Mellars 1989; Straus 1996; Kuhn, Stiner, Reese and Güleç 2001; BarYosef 2002).

For most of the twentieth century, almost everything archaeologists knew about Pleistocene art in general, and rock art in particular, concerned sites in Western Europe, especially southwestern Europe (see, for example, Leroi-Gourhan 1965; Mellars 1989; Gamble 1994; Bahn and Vertut 1997). The privileged position of this area was related both to the history of research and to the richness of the southwestern European archaeological record (McBrearty and Brooks 2000, p. 543). These two factors fueled each other for more than a century: the richness of the southwestern European rock art record has encouraged research in the area, which has increased exponentially the number of discoveries. A consequence of this cycle has been 'the Western European paradigm', the widespread if somewhat implicit assumption that Pleistocene rock art was mainly a Western European phenomenon, exceptions such as Kapova cave notwithstanding (Bader 1965). Archaeologists were persuaded that there was little evidence outside this territory, and even the chronology of the few known examples was questioned. For instance, in Préhistoire de l'art Occidental, Leroi-Gourhan suggested that 'Palaeolithic art covers the most part of Europe [he is including portable art in this statement]. Beyond Europe, documents are few, very strange and poorly dated' (Leroi-Gourhan 1965, p. 277).

During the last twenty years, the Western European paradigm has been called into question. We have witnessed a kind of 'loss of innocence' in Pleistocene art studies, mainly as a result of globalization in the field (Moro-Abadía and GonzálezMorales 2006). Several factors have influenced this change. To begin with, the discovery and dating of Pleistocene decorated caves in United Kingdom (Pettitt, Bahn and Ripoll 2007) and Romania (Clottes et al. 2012) has significantly enlarged 
the geographic footprint of cave art in Europe. Second, recent research in Africa and Asia has shown that parietal art was produced by Pleistocene groups far from Europe. Discoveries such as Qurta in Egypt (Huyge et al. 2007); the open-air sites in the Altai and Mongolia (Molodin and Cherimisin 2002; Jacobson, 2002); Nawarla Gabarnmang in Australia (David et al. 2013); Leang Timpuseng in Wallacea, Indonesia (Aubert et al. 2014); and, more recently, localities in Borneo in Sunda, Indonesia (Aubert et al. 2018) clearly demonstrate that Pleistocene rock art is a global phenomenon. Finally, the restricted distribution of Upper Paleolithic rock art contrasts with the more widespread evidence for other complex behavior, such as portable art (for a compilation, see Bahn 2016), body adornment, funerary practices and the succession of Upper Paleolithic (hereafter UP; $\sim 45,000-13,000$ cal BP) techno-complexes, which extend from the Atlantic to the Don valley in Russia.

Despite the wide acceptance of these more recent discoveries of Paleolithic art outside western Europe, they remain quite geographically isolated, with large gaps between them. This uneven distribution of known UP rock art has led to an almost exclusive research focus on southwestern Europe. The justly famous FrancoCantabrian decorated sites still represent around $80 \%$ of documented Paleolithic rock art worldwide. Thus, while archaeologists are conscious of the narrow view imposed by the 'Western European paradigm', systematic survey of areas outside the heartland is still rare. One of these hitherto neglected areas is the Balkan Peninsula. The Balkans are a key region for studying the Middle and Upper Paleolithic in Europe. Neanderthals and Anatomically Modern Humans (hereafter $\mathrm{AMH}$ ) passed through the region - either along the Danube corridor or the Adriatic coast - Hoffecker 2009; Higham et al. 2012; Chu 2018) and they met and interbred there (Fu et al. 2015). Despite the fact that two major UP migration routes cross the Balkans, archaeological knowledge about the symbolism of Balkan Paleolithic societies is quite limited. Several factors can be evoked to explain this sparse evidence. First, the scarcity of Pleistocene images is somewhat related to the history of research. In fact, before the last 20 years, few research projects had focused on the UP of the Balkans, and even today research in the area is limited when compared to Western Europe (Dogandžić et al. 2014). Second, it is possible that the sparse archaeological evidence reflects a past reality and that production of images was limited among Pleistocene groups in the area. Finally, this sparse evidence could be due to filters on survival of the artworks, such as particular conditions in caves or the use of highly perishable materials as media for decoration. Whatever the case, we still 
require more archaeological research in the area to have a better understanding of the symbolic life of the earliest inhabitants of Europe outside its southwestern part. For this reason, we here synthesize the evidence for UP portable and rock art found in the Balkan Peninsula, including a number of recent discoveries.

\section{The Upper Paleolithic Archaeological Record in the Balkan Peninsula}

The Balkan Peninsula is bounded by the Adriatic Sea to the west, the Mediterranean Sea and the Marmara Sea to the south, and the Black Sea to the east. There is no consensus about its northern boundary. Some authors draw it to overlap with current political frontiers. Nevertheless, from a geographical point of view, the Danube, Sava and Kupa Rivers constitute a natural border for this region, making it roughly coincident with the region known as Southeastern Europe. We will use this limit for this paper. Under this definition, the Balkan Peninsula has a combined area of about $470,000 \mathrm{~km}^{2}$. Its strategic geographical position at the crossroads between Southwest Asia and Central and Western Europe make of this territory a key area for understanding the different human migrations into Europe during the Pleistocene. Nevertheless, as we have mentioned, the archaeological record for UP human occupations in the Balkans remains fragmentary, with important discontinuities and gaps. Additionally, there is a real scarcity of archaeological sites with long, reliable and securely dated sequences (Mihailović et al. 2011; Dogandžić et al. 2014). This fact may well be due to the limited amount of research conducted in the Balkans. Keeping these limitations in mind, we review in this section the evidence corresponding to UP symbolism in the Balkan UP record.

The first arrival of AMH in Europe is represented by several Initial Upper Paleolithic (hereafter IUP) industries. This term, initially proposed by Marks and Ferring (1988) and revisited several times (e.g. Kuhn et al. 1999; Arrizabalaga et al. 2003; Hoffecker 2011), refers to 'the set of early Upper Paleolithic assemblages, from anywhere in the world, with features of Levallois in blank production and essentially Upper Paleolithic retouched tool inventories' (Kuhn and Zwyns 2014, p. 31). IUP industries are present in the northern part of the Balkans, in the sites of Bacho Kiro and Temnata Dupka (Bulgaria). The dates for these occupations are among the oldest UP in Europe: $>46$ cal BP for Bacho Kiro (layer 11) and $>40$ ka cal BP for Temnata (layer 4) (Tsanova 2008). One should be bear in mind that AMH were producing 
figurative rock art in SW Europe by at least 39 ka cal BP (González Sainz et al. 2013; Ruiz-Redondo et al. 2017) and portable art in Central Europe dates back to at least -40-36 ka cal BP (Conard 2009), when these human groups had already passed through the Balkan/Danube corridor (Chu 2018). The Early Upper Paleolithic (hereafter EUP) is unequally represented along the Balkans; sites with Aurignacian assemblages are concentrated mainly in the northern and southern edges of the peninsula. The northern sites are not far from the Danube-Sava corridor, while the southern sites are located in the Peloponnese (Greece). This distribution shows substantial gaps, including the Adriatic coast, where there are no EUP sites known between Šandalja II in Croatia (Karavanić 2003) and Klisoura in Greece (Koumouzelis et al. 2001), with the possible exception of a few surface lithic finds in the Zadar region (Karavanić and Vukosavljević, 2018) and Blazi Cave and the open-air site of Shën Mitri in Albania (Hauck et al. 2016). In the northern group, the Initial Upper Paleolithic industries at Bacho Kiro and Temnata Dupka were followed by the classic early Aurignacian (Kozłowski 1999). The site of Kozarnika (Bulgaria) presents a different kind of EUP lithic assemblage. Its industry, characterized by abundant straight retouched bladelets, has been compared to both the proto-Aurignacian and the Ahmarian (Tsanova et al. 2012). Some potential Early Upper Paleolithic sites have been identified in Eastern Serbia relatively recently (Mihailović et al. 2011; Dogandžić et al. 2014; Mihailović and Mihailović 2014). In Croatia, the sites of Velika Pećina, Vindija and Šandalja II have yielded artifacts resembling Aurignacian implements, but they all come from old excavations and some contexts are uncertain. A new radiocarbon date also suggests an Aurignacian age ( $\sim 34$ ka cal BP) for a massivebased bone point found many years ago in Bukovac Cave in northwest Croatia (Janković et al. 2018). In the southern group, Aurignacian occupations have been documented in the sites of Franchthi (Perlès 1987), Klisoura (Kaczanowska et al. 2010; Koumouzelis et al. 2001) and probably Kephalari as well (Hahn 1984), although information about the chronology and industries of the latter is currently limited.

The period from 34 to $25 \mathrm{ka}$ cal BP in the Balkans (associated with the Gravettian, sensu lato) is characterized by geographical discontinuities and a high degree of internal variability. Known Gravettian sequences include the sites of Temnata and Kozarnika (Bulgaria) as well as the site of Šalitrena Pećina (Serbia). Industries from these sites show some analogies with Central Europe, including the presence of certain elements such as Gravette points, microgravettes and microtruncations (Kozłowski 1999; Tsanova 2003; Mihailović and Mihailović 2007). A 
number of Serbian sites have been ascribed to this techno-complex (Mihailović et al. 2011; Kuhn et al. 2014; Dogandžić et al. 2014), but the small quantity of materials recovered from these sites makes any attribution problematic. And the same can be said of some Croatian sites, including Vindija, Velika Pećina, Šandalja II and Romualdova Pećina. These sites were traditionally related to the Gravettian (Malez 1979), but this attribution is equally problematic. For instance, the post-Aurignacian layers from Vindija have also been attributed to the Epigravettian (Montet-White 1996), and typical Gravettian finds are absent from Velika Pećina (Karavanić 2017). Similarly, the reexamination of the lithic industries from Šandalja II has led archaeologists to define them as Epigravettian (Karavanić 2003). At Romualdova Pećina, the dates indicate an Early Gravettian occupation spanning 34-31.5 ka cal BP (Janković et al. 2017), but the lithic remains are non-diagnostic, and thus should be considered Gravettian sensu lato. In Bosnia and Herzegovina and Montenegro human occupations from this period remain very sparse. In Bosnia and Herzegovina, archaeologists initially proposed a Gravettian chronology for the site of Kadar (MontetWhite and Johnson 1976). However, subsequent analyses seem to indicate an Epigravettian age of 20-18 ka cal BP (Montet-White et al. 1986; Montet-White 1996). In the site of Crvena Stijena (Montenegro), archaeologists initially assigned the layer $X$ to the Aurignacian (Benac and Brodar 1958), but recent analyses seem to indicate a Gravettian chronology (Mihailović 2009). Some distinctive features from this and other Adriatic sites (including the absence of bilaterally-retouched points) have led some authors to propose an independent cultural development for this area, more linked to Central Europe (Mihailović and Mihailović 2007), related to the formation of 'social territories' (Whallon 1999). Recent research in Vrbička Cave (NW Montenegro) brought to light Gravettian age finds dating back to 28000-27000 cal BP (Borić and Cristiani, 2016). Finally, Greek lithic assemblages from this period differ from those from the northern Balkans (Kozlowski 1999). Sites as Asprochaliko (Adam 1989), Franchthi (Perlès 1987) and Kephalari (Hahn 1984) have yielded industries from this period, mainly defined by a high proportion of simple backed blades.

There is no clear break between the Gravettian and the Early Epigravettian in southeastern Europe. In fact, lithic artifacts show a continuity that makes it difficult to establish a clear demarcation line between these two techno-complexes, as has been proposed, for instance, in Italy (Bietti 1990, 1997). Lithic industries from the 'Early Epigravettian' ( 24.5-17.5 ka cal BP) are characterized by straight-backed blades and points. Some authors have suggested the presence of innovations in material culture 
during this period, including shouldered points, typical from the Mediterranean area of the Balkans (from Šandalja II to Kephalari) (Kozłowski 1999), but recent research show that these points can occur almost until the end of the Epigravettian (Vukosavljević and Karavanić 2017). In other areas, the continuity between Gravettian and Epigravettian is so seamless that it has led to misattributions of ages, as in the abovementioned case of Kadar (Montet White et al. 1986).

Finally, the Late Epigravettian ( 17.5-12 ka cal BP) is defined by the appearance of straight-backed bladelets in many Balkan sites (e.g. Šandalja II, Badanj, Crvena Stijena, Salitrena, Franchthi, Klisoura, Temnata), often associated with short end-scrapers (thumbnail and circular types). This period is characterized by a local development of the Epigravettian with specific regional features (Kozlowski 1999; Mihailović 2009). Also during this period, an increasing number of symbolic elements have been documented. The site of Badanj (Bosnia and Herzegovina) illustrates this phenomenon. Dated to $\sim 16-14.5 \mathrm{ka}$ cal BP, this site has yielded a substantial number of body ornaments, several decorated bones and the first evidence of Paleolithic rock art in the Balkans (Basler 1976; Kujundžić 1989; Whallon 1989).

\section{Paleolithic Rock Art in the Balkans}

As discussed in the introduction, scholars traditionally excluded southeastern Europe from the distribution of Upper Paleolithic rock art. It was only in the 1970s that archaeologists discovered the first Balkan Paleolithic image at Badanj, in Bosnia and Herzegovina (Basler 1976). There, Basler documented several lines deeply engraved on a rock surface covered by Epigravettian layers. It was proposed that these lines could represent the rear part of a horse (Basler 1976; Kujundžić 1989), an interpretation that can be questioned on the basis of the published documentation (see below). Badanj remained an isolated case in the Balkan Peninsula for decades. Some years later, close to the eastern and the western borders of the Balkan Peninsula, additional discoveries expanded knowledge of UP rock art. First, in 1978, a number of motifs were discovered at Cuciulat cave (Romania). These included two red paintings, interpreted as a horse and a feline (Cârciumaru and Bitiri 1983; Cârciumaru 2010). Unfortunately, access to this cave was destroyed by quarry activities, so the age of these paintings remains uncertain. In 2009, an assemblage of black paintings was discovered in Peştera Coliboaia, also in Romania. The images include some animal 
representations (Clottes et al. 2012). Some years before, the UP art site of Fumane was discovered in NE Italy. Archaeologists working there dated a number of painted slabs to around 35,000 years ago, based on their stratigraphic position (Broglio and Dalmeri 2005). Until recently, there was just one known UP cave art site, Badanj, lying between Fumane and Peștera Coliboaia, themselves separated by almost a thousand kilometers and representing a gap effectively extending right across the entire Balkan Peninsula. However, in the last few years a number of the authors have conducted archaeological surveys in the area under the auspices of the BALKARTS project, first, and the PALAEOARTEAST project, later; having documented a number of Upper Paleolithic cave art sites. In this section, we summarize the main results of these projects. To date, we have re-examined or documented four sites with rock art in the area: Badanj (Bosnia and Herzegovina); Pećina pod lipom (Bosnia and Herzegovina); Selaćka 3 (Serbia); and Romualdova Pećina (Croatia).

Fig. 1.

Badanj (Bosnia and Herzegovina)

This was the first rock art site assigned to the Upper Paleolithic in the Balkan Peninsula (Basler 1976). This site is located near the town of Stolac, Herzegovina (Fig. 1). The locality consists of a large, deep rock-shelter, with a small cave on its eastern edge. The dimensions of the rock-shelter are $21 \times 8 \times 11 \mathrm{~m}$. The locality is quite visible in the landscape of the valley. $Đ$. Basler was the first to excavate the site in the 1970s (Basler 1976, 1979). He identified prehistoric occupations from the Late Upper Paleolithic.

Excavations were resumed at Badanj in 1986-87 under the direction of $Z$. Kujundžić and R. Whallon. They confirmed the presence of Late Epigravettian and potentially Mesolithic (Fig. 2). Whallon (1989) described a high level of technological and typological continuity throughout the stratigraphic sequence, although the geometric microliths were only present in the uppermost layers. Similarly, most bone and antler tools (mainly awls, pins and needles) show a great deal of similarity through the sequence, but single-row barbed harpoons were recovered only from the upper layers. The body ornaments (consisting of various pierced bone, tooth and shell 
beads) also revealed a high degree of continuity within the sequence, except for Dentalium beads, which were only present in the upper layers. Faunal analysis revealed important changes in the animal species exploited. In the lower layers, red deer (Cervus elaphus, dominant in the entire sequence) is supplemented by ibex (Ibex ibex) and chamois (Rupicapra rupicapra); over time these latter species are gradually replaced by wild pig (Sus scrofa) and roe deer (Capreolus capreolus), almost absent in the older part of the sequence (Miracle 1996). In combination, the observations led Whallon $(1989,1999)$ to define two phases of occupation at the site. He concluded that during both phases the site was occupied by small groups (between 10 and 18 individuals) during early-mid spring (c. March-May). Two radiocarbon dates were first obtained from the sequence (Whallon 1999). The first one, corresponding to the bottom of the sequence (layer 13) provided a ${ }^{14} \mathrm{C}$ age of $13,200 \pm 150 \mathrm{BP}(16,259-$ $15,346 \mathrm{cal}$ BP). The second one comes from layer 6 , in the middle of the sequence, towards the end of the 'older' phase. The ${ }^{14} \mathrm{C}$ age is $12,380 \pm 110 \mathrm{BP}(15,002-14,075$ cal BP), thus suggesting a relatively short duration for the older phase. A third date was later obtained for layer 4 (OxA-5859). The result $(13,200 \pm 110$ BP; 16,186-15,516 cal BP) was considered intrusive, being too recent with respect to its stratigraphic position (Bronk Ramsey et al. 2002).

Fig. 2.

The parietal engravings at Badanj are located on the upper surface of a limestone boulder (Fig. 3). The dimensions of this surface are $\sim 4 \times 2.7 \mathrm{~m}$ and the maximum height of the boulder is $2.3 \mathrm{~m}$. From a frontal view, it is sloped in a W-E direction, with the top of the western edge $2.3 \mathrm{~m}$ above the surface and the eastern margin just a few centimeters above the current cave floor. The entire surface was covered by archaeological deposits until Basler's excavations (Basler 1976, 1979). This fact establishes the Late UP or Early Mesolithic (if the uppermost layer is identified as belonging to that period) as a terminus ante quem for the chronology of the rock art. Four decorated areas can be observed in the western (upper) half of the boulder surface. The graphic motifs consist of a series of geometric engravings, deeply carved in the rock. No remains of pigment have been identified on the rock. Most of the engravings are simple straight lines, sometimes combined or overlapping each other. Their anthropic origin is clear, and the possibility of animal origin (claw 
scratches) can be ruled out based on the following criteria: 1) animal scratches never produce right angles; 2) scratch marks produced by animals are commonly organized in series of 3-4 parallel lines (reflecting the arrangement of their claws); and 3) the Badanj engravings show narrow, V-shaped cross sections, typical of flint tools and very different from the $U$-shaped sections of scratch marks made by the claws of large animals such as bears.

The most interesting part of the engraved surface at Badanj is the upper-left corner, which some archaeologists have interpreted as the rear part of a horse (Basler 1976; Kujundžić 1989). We disagree with this interpretation for several reasons: 1) the engravings barely evoke the rear part of an animal (Fig. 3: right); 2) the style of this representation does not correspond with any other style from the Upper Paleolithic; 3) the lines supposedly depicting the back and the leg of the animal are disconnected; and 4) many of the engravings interpreted as 'filling' this silhouette go beyond its outline. Considering these arguments, the identification of this engraving as figurative should be questioned. In this setting, Badanj's rock art must be interpreted as series of linear, deep and non-figurative engravings, similar to what has been identified at several other UP decorated sites in Europe (e.g. La Viña, El Conde, Cueto de la Mina, El Mirón).

Fig. 3.

Pećina Pod Lipom (Bosnia and Herzegovina)

This site is located close to the town of Sokolac (Fig. 1). Pećina pod lipom is a long rock-shelter ( $-50 \mathrm{~m}$ ) with a variable depth (from 1.5 to $6 \mathrm{~m}$ ) and at least two low, narrow tunnels. Both the excavations and the rock images occur within the rockshelter, close to the larger of the two tunnel entrances. In 1988, archaeologists discovered a decorated panel with engravings that they interpreted as Epipaleolithic or Mesolithic (Kujundžić 1989). The first excavation began in 1990 but was interrupted by the Yugoslav Wars. Twenty-five years later, in 2015, a team led by D. Mihailović resumed work at the site, excavating an area near to the engraved panel. The preliminary results (still unpublished) indicate several periods of occupation. Materials from - at least - the Gravettian/Epigravettian, the Chalcolithic, as well as historical 
periods have been identified in the stratigraphy. For now, archaeologists have not found archaeological evidence from the Mesolithic, the period once claimed for the rock art.

The single decorated panel from this site consists of a series of linear engravings, deeply carved in the rock (Fig. 4). It is located on a sloped wall, to the right of the largest cave entrance. Its dimensions are $1 \times 0.75 \mathrm{~m}$. The panel is profusely decorated with more than eighty linear elements, most straight or slightly curved. The $V$-shaped section is clearly visible in most of them, and they show an eroded patina (Fig. 4.2). These lines constitute no recognizable figurative images, although they meet the same criteria as the Badanj engravings to establish their human authorship. The lower edge of the panel was fractured after its decoration, as the broken lines on this area demonstrate (Fig. 4.3). This opens the possibility of finding some of the fragments in stratigraphic position and establishing a terminus ante quem for the rock art. We suggest a possible Upper Paleolithic chronology on the basis of the following criteria: 1 ) the patina and erosion indicate a prehistoric age for the engravings; 2) there is no clear evidence of Epipaleolithic/Mesolithic occupation of the site; 3 ) the similarity of these motifs (organization, location, technique) to those from Badanj and other Upper Paleolithic sites; and 4) the pronounced dissimilarities with other postPaleolithic rock art sites in the area, such as Ledenjača, Kozlogradske stijene, and Žljeb (Basler 1980).

Fig. 4.

Selačka 3 (Serbia)

This cave is located in the Selačka valley, NE of the town of Knjaževac in eastern Serbia. This valley is located on the slopes of Stara planina mountain range which separates Serbia and Bulgaria (Fig. 1). The site combines two narrow galleries with a somewhat more extensive rockshelter in the front (Fig. 5). In 2012, S. L. Kuhn and D. Mihailović conducted an excavation in the rock-shelter. They identified three major stratigraphic layers, with a series of sub-layers (Kuhn et al. 2014). Layer 1 is a surface deposit with a mix of materials from several historic and prehistoric periods. 
Layer 2 provided a few lithic elements, including two bladelets that could fall within the range of variation of Aurignacian lamelles Dufour. Finally, layer 3 included a number of lithic artifacts such as centripetally worked cores, sidescrapers and denticulated pieces. The authors assigned layer 3 to a fairly recent MP and layer 2 possibly to the EUP. Unfortunately there are no radiometric dates available for the site.

Fig. 5.

In 2012, after surveying the cave walls, we discovered some graphic remains (Ruiz-Redondo 2014; Ruiz-Redondo, Mihailović and Kuhn 2018). They are located five meters away from the main entrance of the cave, on the left wall. They consist of a pair of small red marks, painted directly with fingers. They are parallel and vertical and have an undeniable anthropic origin (Fig. 6). Motifs of this kind are usually called 'paired marks' and are relatively common in Western European UP cave sites (e.g. La Garma, El Castillo, Altxerri B, Cussac). Despite their simplicity, they are not ubiquitous during the Upper Paleolithic, but are most common in the first half of the UP ( 40-24 ka cal BP), where they are often associated with other parietal motifs such as hand stencils and series of dots. We have discussed in previous papers the arguments to for a UP age for Selačka's paintings (Ruiz-Redondo 2014; RuizRedondo et al. 2018), concluding that it could be the parsimonious hypothesis. In 2017, we opened a trench below the paintings. The main objective was to contextualize the graphic remains and to define a chronology for them. The stratigraphy was deeply disturbed, including Paleolithic and historic materials throughout the whole sequence. In this setting, we can only suggest a Paleolithic chronology of these paintings based on the abovementioned evidence, as proposed for Pećina pod lipom.

Fig. 6. 
Romualdova Pećina (Croatia)

The site of Romualdova Pećina is located in the west of the Istrian Peninsula, on the southern shore of the Lim channel (Limski kanal) (Fig. 1). It is a deep cave with a single gallery, situated $106 \mathrm{~m}$ above current sea level. With a length of more than $110 \mathrm{~m}$, this is the deepest cave in the area. The entrance is one meter high and is almost completely filled by sediment. Three campaigns of archaeological excavations have been undertaken at Romualdova Pećina since the end of the $19^{\text {th }}$ century (see Janković et al. 2017). In 1960s, M. Malez (1981) re-excavated the site and identified a number of human occupations from the Bronze Age and the Early Upper Paleolithic. The projects undertaken later by D. Komšo (2008) and I. Janković confirmed the existence of two occupation levels and documented a lower layer that yielded several lithic tools assigned to the Middle Paleolithic on a typological basis (Janković et al. 2017). They identified and dated three periods of occupation corresponding to the Middle Paleolithic, the Early Upper Paleolithic and the Bronze Age. The EUP layers are rich in faunal remains (including bison and ibex bones from previous excavations: Malez 1981). Lithic artifacts are sparse, however, and the small collection is not diagnostic of any particular techno-complex. Among the few retouched flint pieces, there is a backed bladelet, an almost ubiquitous type during the Mid and Late UP in the Balkans. Lithic artifacts are more numerous in the MP layers and suggest a late chronology within this period.

Fig. 7.

In 2010, D. Komšo discovered some red paintings in the deep part of the cave and suggested that they were of a Paleolithic age. We studied the site in 2017 in the context of the BALKARTS project. We were able to identify at least 44 graphic units (GU), located in an area between about 32 and $46 \mathrm{~m}$ from the entrance (RuizRedondo et al. 2019). All of the images are painted or drawn using red ochre. In spite of the poor preservation, we were able to identify the first figurative rock art in the Balkans (Fig. 8): a representation of a bison, an ibex and two possible anthropomorphic figures (for a detailed description of these figures, see Ruiz- 
Redondo et al. 2019). Both ibex and bison display some typical features of UP representations (see Discussion section below). The anthropomorphic figures are schematic and represented in profile, similarly to other UP human figures. We interpret them as 'males' as the phallus seems to be represented and they lack any typical female features (breast or pubic triangle). In order to contextualize the paintings, we excavated a small $(1 \times 1.5 \mathrm{~m})$ trench below them. Under a $\sim 5 \mathrm{~cm}$ surface layer and a $\sim 20-30 \mathrm{~cm}$ sterile clay layer, we found a thin stalagmite crust that covered the entire excavated surface. On top of that crust we recovered some Upper Paleolithic materials. The most significant are a fragment of a red ochre crayon $(\sim 1.5 \mathrm{~cm})$, other additional small fragments of ochre, several small fragments of charcoal and a flint blade. The accumulation of these materials is undeniably anthropogenic (Ruiz-Redondo et al. 2019). Three charcoal samples were taken from the stalagmite crust surface where the ochre fragments and the flint blade were lying. Two of the resulting dates overlap at $\sim 17 \mathrm{ka}$ cal BP, while the third one is more recent $(\sim 12.7 \mathrm{ka} \mathrm{cal} \mathrm{BP})$.

The precise chronology of the rock art site is difficult to determine. The iconography (including a bison, extinct in this area at the end of UP), style and technique seem to indicate a Paleolithic age for these images. Additionally, a modern inscription dated from 1880 crossing the ibex representation suggests that the paintings are not a modern forgery: it pre-dates the recognition of the existence of Paleolithic cave art by 22 years (Cartailhac 1902). Although this inscription could also be a recent fake, it does show patina suggesting that it is in fact old. Taking all evidence into account, two alternative chronological hypotheses can be proposed (for a more detailed discussion, see Ruiz-Redondo et al. 2019). The first hypothesis is that the paintings are from the EUP ( $34-31 \mathrm{ka}$ cal BP). This proposal fits well with the style of the paintings (with several analogies with the Gravettian portable and rock art from Western Europe) and with the occupations identified in the excavations at the entrance of the cave. On the other hand, if this hypothesis is correct, then (a) the immediate archaeological context of the paintings is a mixture of remains from several periods; (b) the radiocarbon samples are contaminated; or (c) none of the materials (ochre, flint and charcoal) are related to the graphic activity. We did not reach the bedrock at the trench below the panel, so we cannot exclude the possibility that older archaeological layers could be present under the calcite crust; further excavations are planned. The second hypothesis suggests an Epigravettian ( $17 \mathrm{ka}$ cal BP) age for the paintings. This hypothesis is consistent with two of the 
charcoal samples from the immediate archaeological context of the artworks. However, if we accept this hypothesis, then it is necessary to explain (a) the lack of clear evidence of other human occupations from that period in the cave, and (b) the stylistic similarities with earlier decorated sites from the EUP. Given the present state of the documentation, it is impossible to weight either hypothesis more heavily. Despite this uncertainty, the Paleolithic age of the paintings seems to be certain. In this context, the discovery of the animal images at Romualdova is an important milestone in the knowledge of UP symbolism in Europe, demonstrating the existence of figurative rock art in the Balkan Peninsula.

Fig. 8..

\section{Upper Paleolithic Portable Art in the Balkans}

Archaeologists have traditionally divided Paleolithic art into two main categories: parietal art (= 'rock art') and portable art (= 'mobiliary art'). Although some scholars have argued that this distinction is exclusively a modern construction (Moro Abadía and González-Morales 2003, 2004), we retain it here for practical purposes. The term portable art covers a wide range of objects made from different materials (bone, antler, stone, ceramic), using a variety of techniques (painting, engraving, sculpture), associated with different kinds of artifacts (functional artifacts, non-functional pieces, decorated raw materials) and diverse iconography (animal representations, human figures, structured signs, simple motifs). Although 'personal ornaments' are sometimes included in this category, we have excluded them here as they certainly played a different role in UP symbolic culture than the mobiliary art. Although they have been variously described as 'conveyors of the social identity of persons' (Zilhão 2007, p. 35), artifacts reflecting 'changing social and demographic conditions' (Kuhn and Stiner 2007, p. 48), or 'markers of ethnic, social and personal identity' (Vanhaeren and d'Errico 2005, p. 542) - descriptions that could also be applied to portable art - important differences in their use (personal ornaments are probably made to be clearly visible) or their iconography (more limited and normally 
non-figurative in the case of personal ornaments) make us reluctant to include both kind of objects in the same category. On the other hand, research interest on Paleolithic personal ornaments has increased significantly since the 1990s (for a compilation see Moro Abadía and Nowell 2015). A panoply of methods and theories have been developed for their analysis; their application to the Balkan archaeological record would go beyond the scope of this paper.

Excluding beads, the number of items to be considered UP 'mobiliary art' in the Balkans is relatively low. This could be due to a research bias and/or it could reflect specific social and cultural traits of human groups of the area. It is noteworthy, for instance, that a total of 50 UP sites are known for Croatia, Bosnia and Herzegovina, Serbia and Montenegro together, whereas 235 UP sites are documented in the French department of Dordogne, an area 1/23 its size (RuizRedondo et al. 2019). But even if the intensity of research is clearly a factor to consider, behavioral differences between UP Balkan populations and others cannot be dismissed. The fact that only a small number of UP sites have been documented in the Balkans does not explain why decorated items are rare even in the sites where they appear. Classic Western European sites as Laugerie, Isturitz, Altamira, EI Castillo or Parpalló have each yielded several times more decorated objects that the total discovered in the Balkans from the entire UP.

The oldest UP decorated objects in the Balkans are more than 40,000 years old. They come from the Bulgarian sites of Temnata Dupka and Bacho Kiro and are in both instances associated with IUP lithic industries. At Temnata, an engraved schist rock was found in Layer VI of the sector TD-II (Crémades et al. 1995). A single radiocarbon date for this layer yielded a minimum age of $38.7 \mathrm{ka} B P$. The lithic industry has been defined as 'transitional' between the MP and the Aurignacian (Kozłowski et al. 1989). However, a taphonomic study suggests that the material from this layer could be the result of the accumulation of two different components: MP and EUP (Tsanova 2009). This possibility is consistent with the geoarchaeological analysis (Ferrier and Laville 1992). In any case, the materials from these layers seem to date from between 56 and $40 \mathrm{ka}$ cal BP (Tsanova 2008). The decorated item is a quadrangular fragment of stone, with maximum dimensions of $9.1 \times 3.6 \times 1.1 \mathrm{~cm}$ (Fig. 9-1). One broad, flat face and one edge are decorated. The decoration consists of two series of 21 engraved elements each. There are differences in the profile of the engravings of each series: $V$-shaped on the edge and 
U-shaped on the flat side. According to Crémades et al. (1995) this is probably related to a change in the technique, not to a change in the tool used to carve. A decorated bone fragment was found at the site of Bacho Kiro. It was first thought to come from Layer 12 (Marshack 1982), but later it was proposed that it originated in Layer 11 or 11 a (Guadelli 2004, 2005). Both layers yielded IUP-like lithic assemblages, and the radiocarbon dates indicate a chronological range between 46 and $37 \mathrm{ka}$ cal BP (Tsanova 2006). The bone fragment is $9.9 \mathrm{~cm}$ long, $2.9 \mathrm{~cm}$ wide and $0.95 \mathrm{~cm}$ thick. Its surface has been scraped and polished (Marshack 1982). The decoration consists of a series of engraved zigzag lines (Fig. 9-2).

Two other pieces of mobile art have been attributed to the Aurignacian. At Šandalja II (Croatia), a fragment of bone with two series of parallel incisions was found at Layer E ('Aurignacian'; Karavanić 2003). The length of this item is $6.2 \mathrm{~cm}$, and its maximum width is $1.6 \mathrm{~cm}$ (Fig. 9-3). Another eight decorated objects have been found in this site, and this is the only one attributed to the Aurignacian (the rest are from the Epigravettian; see below). Coming from an old excavation at a site that no longer exists, and considering the analogies between this and other items in the collection, its stratigraphic position has been questioned, suggesting the possibility that it also derived from the Epigravettian layers (Čujkević-Plećko and Karavanić 2018). At the site of Mala Gradina (Bosnia and Herzegovina), the Aurignacian layer 5 yielded an object interpreted as 'mobiliary art'. It is a naturally shaped stone evoking a bird's (duck's) head. Its dimensions are $\sim 5 \times 2 \times 1 \mathrm{~cm}$ and Basler proposed that the eyes have been intentionally carved (Basler 1978, 1979). The dimensions, the nature and the limited documentation published indicate that we should withhold judgment on the anthropic nature of this piece for the time being.

For the period 34-25 ka cal BP (Gravettian sensu lato), only one decorated piece has been found in the Balkans, at the site of Kozarnika (Bulgaria). It is a small $(\sim 2 \times 2 \mathrm{~cm})$ fragment of a Paleolithic 'Venus' figurine (Sirakov et al. 2014; Fig. 9-4). It is made on a herbivore bone, probably bison, and it was accidentally broken during the manufacturing process. This suggests that this piece was probably made - and eventually discarded - in situ. Its fragmented state makes a detailed analysis difficult, but the characteristic steatopygia of the Gravettian Venus figurines is noticeable. The statuette was not originally identified during the excavation, but came from sieving of Layer IV ( $\mathrm{a}$ and $\mathrm{b}$ ), which makes the likely chronological frame between 28.5 and 26.5 ka cal BP (Sirakov et al. 2014, p. 27). 
Fig. 9.

Two decorated items have been attributed to the Early Epigravettian, but for one of them the existence of a symbolic background remains uncertain. In the site of Šandalja II (Croatia) an item was found in Layer C/d (Malez 1987). An old radiocarbon date places the deposit of this layer at around 25 ka cal BP (Srdoč, Sliepčević, Planinić, Obelić and Breyer 1973). The object is a fragment of bone, polished in all its surfaces (Fig. 10-1). There are four engraved lines that cross one of the sides, along with 26 short engravings, perpendicular to the first of the long lines (Čujkević-Plećko and Karavanić 2018). Its shape and technical work evokes a spatula, but its fragmentary state prevents clear identification. Dating to approximately the same period, stratum 5 from Kastritsa (Greece) yielded a long-bone shaft fragment bearing some 'grooved lines' on its dorsal surface (Kotjabopoulou and Adam 2004). The authors do not exclude the possibility that this pattern could be due to butchering activity, so its symbolic nature is open to debate.

Fig. 10.

The Late Epigravettian has yielded the largest number of decorated items in the Balkan Peninsula. Their geographical distribution is also wider than in previous periods. In Croatia, the sites of Šandalja II, Pupićina, Vlakno and Vela Spila have yielded several objects of mobiliary art. In the first, five decorated items were found in the ' $\mathrm{B}$ ' complex and another in the $\mathrm{B} / \mathrm{C}$ interface. According to the radiocarbon results (Malez and Vogel 1969; Miracle 1995; Oros Sršen et. al. 2014; Richards, Karavanić, Pettitt and Miracle 2015), this complex dates to 15 to $12.7 \mathrm{ka}$ cal BP. Three of the decorated objects are bone tools (Fig. 10-3, 10-4, 10-5), two are bone fragments (Fig. 10-6, 10-7) and one is a part-cortical bladelet (Fig. 10-2), with engravings in its cortex (Čujkević-Plećko and Karavanić 2018). Both the bladelet and a fragment of flat bone present crosshatch motifs. The three bone tools (two awls and a point) are decorated 
with a number of parallel engravings. Finally, one bone fragment presents a series of convergent (roughly 'V-shaped') engravings. In Pupićina, the late Epigravettian layer (around $13.4 \mathrm{ka}$ cal BP) yielded a fragment of long-bone displaying a series of parallel incised marks (Komšo 2005). The bone fragment and its decoration closely resemble a piece from Šandalja II (Fig. 10-4) and another from Badanj (Fig. 12-13). In the site of Vlakno, two engraved fragments of chert nodules were found in a Late Epigravettian layer, dated by radiocarbon between 14.6 and 14 ka cal BP (Vujević and Parica 2010). They are both small pieces (less than $3 \mathrm{~cm}$ long). One presents at least two series of parallel engravings from the edges to the center of the fragment (Fig. 11-2). The second has a single series of sub-parallel engravings bordered by two transversal elements (Fig. 11-1). In the same layer, an anthropomorphic-shape pendant made on bone was also found. It is decorated with a ladder-like incised motifs (Vujević 2018). The site of Vela Spila has yielded 36 ceramic fragments that constitute the most exceptional findings (Farbstein et al. 2012). They were recovered in Late Epigravettian layers (LUP-D to LUP-G), which date to c. 17.5-15.5 ka cal BP. One of the fragments has been identified as part of a statuette, representing the torso and foreleg of an animal, perhaps a horse or deer (Fig. 11-3). A second piece might represent an animal's hindquarters (Fig. 11-4). This fact, together with the comparison between these pieces and other UP ceramic statuettes (e.g. Pavlov, Dolní Věstonice) has led the researchers to propose that all the fragments could belong to other symbolic items.

Fig. 11.

The site of Badanj (Bosnia and Herzegovina) yielded the largest assemblage of decorated bones and antlers in the Balkans. The collection has never been exhaustively studied and the exact number of decorated items remains unknown. A selection of 17 of these artifacts was published in the 1980s (Kujundžić 1989), constituting a minimum number for the assemblage of decorated items (Fig. 12). Some are natural and others are modified fragments of bones and antlers. They came both from the older (c. $16 \mathrm{ka} \mathrm{cal} \mathrm{BP)} \mathrm{and} \mathrm{the} \mathrm{recent} \mathrm{(c.} 14.5 \mathrm{ka}$ cal BP) phases 
(Whallon 1999). The motifs represented seem to be quite similar in the two periods: series of parallel lines, zigzags, convergent or isolated lines. A new study of this important assemblage is required before further conclusions can be reached.

Fig. 12.

Finally, in stratum 1 of Kastritsa (Greece), researchers found a decorated fragment of an artifact made on antler (Kotjabopoulou and Adam 2004). According to old radiocarbon results, this layer is dated to c. 16 ka cal BP (Bailey, Carter, Gamble and Higgs 1983; Adam 1999), while more recently obtained determinations series date Stratum 1 at c. $19 \mathrm{ka} \mathrm{cal} \mathrm{BP} \mathrm{(Galanidou} \mathrm{and} \mathrm{Tzedakis} \mathrm{2001).} \mathrm{The} \mathrm{original} \mathrm{form} \mathrm{of} \mathrm{the}$ artifact cannot be identified due to its fragmentary state, but it has been modified and heavily polished. This fragment bears two series of short parallel engravings on both lateral edges, in number seven and eight. Another worked bone was found in the same stratum. It is compared to the bone discs (rondelles) from the SW-European Magdalenian (Kotjabopoulou and Adam 2004), but because it does not exhibit a hole or engravings, we decided to exclude it from our inventory.

\section{Discussion}

In this paper, we have presented and discussed all evidence of Upper Paleolithic art currently known from the Balkans, providing a general overview of the material evidence of symbolism of the late Pleistocene societies in the region. The overview combines old and relatively new discoveries that show the potential of a traditionally neglected area in terms of Paleolithic research. Considering the state of knowledge and the full range of evidence, we briefly address some further issues in this section.

The Discovery of Cave Art in the Balkans 
Archaeological knowledge of the Paleolithic in general, and of rock art specifically in the Balkans has increased substantially in the last few years. Although it cannot match the richness of the Western European record, the general view has certainly been transformed. In a short amount of time, the Balkan peninsula has shifted from a terra incognita to a promising area. This phenomenon has been influenced by a combination of factors. First, the increasing interest in the regional Paleolithic since the 1990s resulted in a number of discoveries and a better understanding of previously known sites. Second, these discoveries confirmed the relevance of the area for Paleolithic studies. Finally, the new evidence, combined with the geographic position of the Balkans along several potential routes of dispersal, and the increasing number of UP rock art discoveries outside of southwest Europe, has aroused the interest of specialists in UP symbolism. This has attracted more international interest to the area (see for instance Mihailović 2014), leading to the creation of collaborative projects involving specialists from different countries.

While ten years ago UP rock art in the Balkans was restricted to a single boulder with several linear engravings, today four sites are documented. Despite the small quantity of finds, this has significantly enlarged the pool in terms of variability. Pećina pod lipom could be easily linked to Badanj due to its style, technique and, probably, chronology. Selačka 3 shows some original features compared to the Bosnian sites: 1) it has paintings and not engravings; 2) the motifs are located inside the cave and not in the external rock-shelter; and 3) its chronology - if Paleolithic seems to be significantly older than that of Badanj and Pećina pod lipom. Finally, the discovery of Romualdova pećina extends the variability of the Balkan graphic record. If the current preservation of the paintings makes it impossible to consider the site a major Paleolithic sanctuary, it at least represents an important deep-cave parietal ensemble. Despite the fact that most of them cannot be properly interpreted, the number of motifs is significant. Among them, at least two, and probably four, figurative representations have been identified, demonstrating for first time the presence of figurative art in the Balkans. Their style is noticeably Paleolithic and analogies with other UP images can be established. For instance, the bison has some specific conventions (simple outline of the upper part, 'U'-shaped horns) that link it with some other representations in Europe. Close analogies can be found in the Gravettian portable and rock art from Western Europe (Jaubert 2008; Rivero and Garate 2014), but also in Aurignacian-age art from cave sites such as Chauvet (Clottes 2001) and Coliboaia (Clottes et al. 2012). Defining a precise chronology for the Romualdova 
paintings must be a priority in order to better integrate the symbolism from the Balkans into the emerging picture of European Paleolithic social and cultural dynamics.

Portable Art: Chronological and Geographical Transformations

Although the picture of mobiliary art in the Balkan Peninsula has become more complete during the last 20 years, discontinuities are still present. When analyzing the chronological and geographical distribution of this phenomenon, any interpretations and conclusions must be taken as preliminary. Nevertheless, some features revealed by the currently available data deserve further discussion.

The distribution of mobiliary art items is irregular and discontinuous in both geographical and chronological frames. The oldest examples, from the sites of Temnata Dupka and Bacho Kiro, both in Bulgaria, belong to the IUP. Also from that area is the so-called 'Venus' from Kozarnika, the only example of Gravettian portable art in the Balkan Peninsula. Also attributable to the first half of the UP are the items from Mala Gradina (Bosnia and Herzegovina) and Šandalja II (Croatia). However, the anthropogenic origin of modifications on the first specimen is not clear, and the stratigraphic position of the second is questioned (Čujkević-Plećko and Karavanić 2018). For the Early Epigravettian, the symbolic character of the bone recovered in stratum 5 of Kastritsa (Greece) is dubious even for its discoverers (Kotjabopoulou and Adam 2004), leaving the bone from Layer C/d of Šandalja II as the only potential piece of portable art from the period: here we must remember that it comes from old excavations, it is isolated and its typology is not clear. However, for the Late Epigravettian, the sites of Šandalja II, Pupićina, Vlakno, Vela Spila, Badanj and Kastritsa have yielded a broader range of portable art, including decorated bones and bone tools, engraved stones and ceramic statuettes.

Regarding the chronology of these archaeological remains, we can differentiate two major periods. The first one, corresponding to the Early and Middle Upper Paleolithic, is associated with a small number of items from the northeast of the Balkans, specifically from three Bulgarian sites. The typology of these items is not diagnostic in the case of the schist rock and the bone: parallel lines and zigzags are common motifs for different periods of the UP. On the other hand, the 'Venus' shows 
clear links with areas such as Moravia (Svoboda 1995) and Russia (Svoboda 2007). The associated date for this statuette, between 28.5 to $26.5 \mathrm{ka}$ cal BP (Sirakov et al. 2014), fits well into the chronological range for this kind of representation in other parts of Europe. The second period corresponds to the Late Epigravettian. In this period, the axis has moved west, from the Balkan Mountains and Lower Danube to the Adriatic and Ionian coast. Also the cultural contacts seem to have moved towards the west. The particular ceramic sculptures from Vela Spila have no parallels in the late Upper Paleolithic of Europe. However, the other items decorated with geometric engraved patterns resemble artifacts from the Italian Epigravettian (e.g. Grotta di Settecannelle; Ucelli Gnesutta and Cristiani 2002), which might point to links previously observed in other archaeological material, such as the lithic industries or personal ornaments (Borić and Cristiani 2016).

Integration of the UP Symbolic Culture of the Balkans in European Social and Cultural Dynamics

The raw materials and the images on portable art recovered in the Balkans show a high degree of variability. There are female figurines (Kozarnika), whose analogues can be found at a number of Gravettian sites from the Pyrenees to the Urals (Gaudzinski and Jöris 2015). The ceramic sculptures (Vela Spila) are well known in other regions during the UP, especially in the Pyrenees and in the presentday Czech Republic (Bougard 2010). Nonetheless, the Late Epigravettian age of the Croatian site makes them 'unique' in the context of the UP symbolic culture. The geometric forms engraved in bone or stone items, including the reticulate pieces (Šandalja II, Vlakno) are also relatively common, and have been found in layers of similar age at the famous portable art sites such as Parpalló (Villaverde 1994).

The beginning of research focused specifically on UP rock art has led to the discovery of new sites and figurative representations. These results seem to support the first of the three hypotheses mentioned in the introduction: the sparse archaeological evidence for art could be mainly due to a parallel sparseness in systematic research. It is not impossible that UP human groups in this area simply did not produce and use rock art as often as people in some other parts of Europe, but the conventional features shown by the artworks do not support this interpretation. Finally, the use of perishable materials (wood, skin, body 
painting/tattooing) as media for graphic expression cannot be addressed directly. A combination of these three elements is a real possibility that should be considered, but the promising start of the Paleolithic art surveys in the Balkans seems to highlight the effects of research bias. In any event, that is the one bias that can be remedied directly.

Despite the scarcity of rock art in the Balkans, some morpho-stylistic analogies for figurative and non-figurative images can be found in the rich corpus of southwest European cave art. The 'paired marks' (Selačka 3) are one of the most frequent motifs in Spanish and French cave sites during the Early and Middle UP (Ruiz-Redondo 2014; Ruiz-Redondo et al. 2018). The color and the technique (made directly with two fingers) are also typical in southwest Europe. The deeply engraved patterns in the external area of the caves or rock-shelters (Badanj pećina, Pećina pod lipom) vividly evoke several northern Spanish sites, where similar patterns are represented, in some cases associated with animal engravings (Garate 2013). The figurative rock art in the Balkans currently consists of some red paintings, including a bison, an ibex and two possible human figures (Romualdova pećina). Both bison and ibex are commonly represented species in European UP cave art. The particular stylistic features of Romualdova's figures link them to others from EUP decorated sites (Ruiz-Redondo et al. 2019).

\section{Conclusion}

In this paper, we have summarized and synthesized the record of Upper Paleolithic graphic expression from the Balkans. Recent discoveries and research in this area have led to new insights into symbolism and social and cultural interactions in this part of the continent. This record shows a high variability in the contacts and influences, depending on the age and the geographic area. The first mobiliary art is almost as old as the first entry of $\mathrm{AMH}$ into this region and it is confined to the northern area, in the Lower Danube. Its features are not diagnostic of any period or region: they fall into the general range of EUP symbolic behavior. During the Gravettian sensu lato, in the same area, a fragment of a 'Venus' figurine (Kozarnika) evokes contacts with central and northeastern Europe (from southern Germany to the Russian Plain). But in other parts of the peninsula (Selačka 3 and Romualdova pećina), some red paintings may express relationships with southwest European 
populations (Franco-Cantabrian province), if the chronology can be confirmed. Finally, at the end of the Paleolithic, the sites in the Adriatic and Ionian basins yield evidence that links them to the Italian Epigravettian (mobiliary art in Šandalja II, Vlakno, Badanj and Kastritsa). On the other hand, the rock art in Badanj and Pećina pod lipom and unusual ceramic figurines in Vela Spila show a distinctive local character.

In total, the evidence of Paleolithic symbolism in the Balkans moves between commonness and originality, and its analogies and influences can be tracked to different parts of Europe. We must recognize that these conclusions are based on the very limited corpus of UP decorated items and parietal art currently available, and thus likely reflect only a small part of the picture. We have captured certain glimpses of the symbolic culture of the Paleolithic societies, which seems to have been more complex and rich than supposed just a few years ago. This promising start shows the potential of the region and argues for further research in Paleolithic art in this and other 'neglected' areas in the near future.

\section{Acknowledgements}

Most of the results presented in this manuscript are part of the BALKARTS (Looking for the Origins of Art: BALKans Archaeological Rock arT Survey) project, led by AR$\mathrm{R}$, and funded by the French State within the framework of the 'Investments for the future' Programme IdEx University of Bordeaux (reference ANR-10-IDEX-03-02). AR$\mathrm{R}$ has also received financial support from the British Academy through a Newton International Fellowship. We are grateful to the Archaeological Museum of Istria (AMI) for contributing its technical and human resources to the work in Romualdova pećina. In Serbia, this work has received financial support from the Ministry of Culture and Information and the Ministry of Education and Science of the Republic of Serbia, project no. 177023. We are thankful to D. Vujević (Dept. of Archaeology, University of Zadar) for sharing with us contextual data about portable art from Vlakno cave and for providing photos of materials from the site shown in figure 9. 


\section{References}

Adam, E. (1989). A technological and typological analysis of Upper Palaeolithic stone industries of Epirus, North-Western Greece. BAR International Series 512. Oxford: British Archaeological Reports.

Adam, E. (1999). The Upper Palaeolithic stone industries of Epirus in their regional setting. In G. N. Bailey, E. Adam, E. Panagopoulou, C. Perlès, \& K. Zachos (Eds.), The Paleolithic archaeology of Greece and adjacent areas. Proceedings of the ICOPAG Conference, Ioannina, September 1994. British School at Athens Studies, 3 (pp. 137-147). Athens: British School at Athens.

Arrizabalaga, A., Altuna, J., Areso, M., Elorza, M., García, M., Iriarte, J., Mariezkurrena, K., Mujika, J., Pemán, E., Tarriño, A., Uriz, A., Viera, L., \& Straus, L. G. (2003). The initial Upper Paleolithic in Northern Iberia: New evidence from Labeko Koba. Current Anthropology, 44, 413-421.

Aubert, M., Brumm, A., Ramli, M., Sutikna, T., Saptomo, E. W., Hakim, B., Morwood, M. J., van den Bergh, G. D., Kinsley, L., \& Dosseto, A. (2014). Pleistocene cave art from Sulawesi, Indonesia. Nature, 514, 223-227.

Aubert, M., Setiawan, P., Oktaviana, A. A., Brumm, A., Sulistyarto, P. H., Saptomo, E. W., Istiawan, B., Ma'rifat, T. A., Wahyuono, V. N., Atmoko, F. T., Zhao, J.-X., Huntley, J., Taçon, P. S. C., Howard, D. L., \& Brand, H. E. A. (2018).

Palaeolithic cave art in Borneo. Nature, 564, 254-257.

Bader, O. N. (1965). Kapovaya peschera. Moscow: Nauka.

Bahn, P. G. (2016). Images of the Ice Age. Oxford: Oxford University Press.

Bahn, P. G., \& Vertut, J. (1997). Journey through the Ice Age. London: Weidenfeld \& Nicolson.

Bailey, G., Carter, P. L., Gamble, C. S., \& Higgs, H. P. (1983). Asprochaliko and Kastritsa: Further investigations of Palaeolithic settlement and economy in Epirus (North-West Greece). Proceedings of the Prehistoric Society, 49, 12-42.

Bar-Yosef, O. (2002). The Upper Paleolithic revolution. Annual Review of Anthropology, 31, 363-393.

Basler, Đ. (1976). Paleolitsko prebivalište Badanj kod Stoca. Glasnik Zemaljskog muzeja Bosne i Hercegovine (A) n.s. sv., 29, 5-18.

Basler, Đ. (1978). Paleolitsko nalazište Mala Gradina u Kulašima. Članci i Građa za kulturnu istoriju istočne Bosne, XII, 9-16.

Basler, Đ. (1979). Le Paléolithique final en Herzegovine. In D. Sonneville-Bordes (Ed.), La fin des temps glaciaires (pp. 345-355). Paris: CNRS.

Basler, Đ. (1980). Pećinski crteži u istočnoj Bosni. Naš krš, VI(8), 65-76.

Benac, A., \& Brodar, M. (1958). Crvena Stijena -1956. Glasnik Zemaljskog muzeja Bosne i Hercegovine (A) n.s. sv., 13, 21-65. 
Bietti, A. (1990). The Late Upper Palaeolithic in Italy: An overview. Journal of World Prehistory, 4(1), 95-155.

Bietti, A. (1997). Considération sur la definition de l'Epigravettien ancient en Italie. In J. M. Fullola, \& N. Soler (Eds.), El Món Mediterrani després del Pleniglacial (pp. 131-146). Girona: Museu d'Arqueologia de Catalunya.

Borić, D., \& Cristiani, E. (2016). Social networks and connectivity among the Palaeolithic and Mesolithic foragers of the Balkans and Italy. In R. Krauß, \& H. Floss (Eds.), Southeast Europe before Neolithisation (pp. 73-112). Tübingen: University of Tübingen.

Bougard, E. (2010). The use of clay in the Upper Palaeolithic of Europe. BAR International Series 2069. Oxford: Archaeopress.

Broglio, A., \& Dalmeri, G. (Eds.) (2005). Pitture paleolitiche nelle Prealpi venete. Grotta di Fumane e Riparo Dalmeri. Memorie Museo Civico di Storia Naturale di Verona: Sezione Scienze dell'Uomo, vol. 9. Verona: Museo Civico di Storia Naturale.

Bronk Ramsey, C., Higham, T., Owen, D. C., Pike, A. W. G., \& Hedges, R. E. M. (2002). Radiocarbon dates from the Oxford AMS system: Archaeometry datelist 31. Archaeometry, 44(3), sup. 1, 1-149.

Cârciumaru, M. (2010). Contributions à la connaissance de l'art pariétal préhistorique de Roumanie. Annales de l'Université 'Valahia', 12(1), 39-83.

Cârciumaru M., \& Bitiri, M. (1983). Peintures rupestres de la grotte de Cuciulat (Roumanie). Bulletin de la Société Préhistorique Française, 80(3), 94-96.

Cartailhac, E. (1902). La grotte d'Altamira, Espagne. Mea culpa d'un sceptique. L'Anthropologie, 13, 348-54.

Chu, W. (2018). The Danube Corridor Hypothesis and the Carpathian Basin: Geological, environmental and archaeological approaches to characterizing aurignacian dynamics. Journal of World Prehistory, 31(2), 117-178.

Clottes, J., Besesek, M., Gély, B., Ghemis, C., Kenesz, M., Lascu, V. T., Meyssonnier, M., Philippe, M., Plichon, V., Prud'homme, F., Radu, V. A., Rus T., \& Tociu, R. L. (2012). Découverte d'une nouvelle grotte ornée paléolithique en Roumanie, dans le département du Bihor. In J. Clottes (Ed.), L'art pléistocène dans le monde. Actes du Congrès IFRAO, Tarascon-sur-Ariège, septembre 2010, Symposium «Art pléistocène en Europe» (pp. 513-528). Tarascon: Préhistoire, Art et Sociétés-B.S.P.A 65-66.

Conard, N. J. (2009). A female figurine from the basal Aurignacian of Hohle Fels Cave in southwestern Germany. Nature, 459, 248-252.

Crémades, M., Laville, H., Sirakov, N., \& Kozłowski, J. K. (1995). Une pierre gravée de 50000 ans BP dans les Balkans. Paléo, 7, 201-209.

Čujkević-Plećko, M., \& Karavanić, I. (2018). Carved finds from Šandalja II. Histria archaeologica, 48, 5-20. 
d'Errico, F. (2003). The invisible frontier: A multiple species model for the origin of behavioural modernity. Evolutionary Anthropology, 12, 188-202.

David, B., Geneste, J.-M., Petchey, F., Delannoy, J.-J., Barker, B., \& Ecclestone, M. (2013). How old are Australia's pictographs? A review of rock art dating. Journal of Archaeological Science, 40(1), 3-10.

Dogandžić, T., McPherron, S., \& Mihailović, D. (2014). Middle and Upper Paleolithic in the Balkans: Continuities and discontinuities of human occupations. In D. Mihailović (Ed.), Palaeolithic and Mesolithic research in central Balkans (pp. 8396). Belgrade: Serbian Archaeological Society.

Farbstein, R., Radić, D., Brajković, D., \& Miracle, P. T. (2012). First Epigravettian ceramic figurines from Europe (Vela Spila, Croatia). PLOS ONE, 7(7), e41437. doi:10.1371/journal.pone.0041437

Ferrier, C., \& Laville, H. (1992). Stratigraphie des dêpots de la grotte Temnata. In J. K. Kozlowski, H. Laville, \& B. Ginter, (Ed.), Temnata cave: Excavations in Karlukovo karst area, Bulgaria. Vol. I.1 (pp. 49-64). Krakow: Jagellonian University Press.

Fu, Q., Hajdinjak, M., Moldovan, O. T., Constantin, S., Mallick, S., Skoglund, P., Patterson, N., Rohland, N., Lazaridis, I., Nickel, B., Viola, B., Prüfer, K., Meyer, M., Kelso, J., Reich, D., \& Pääbo, S. (2015). An Early Modern Human from Romania with a recent Neanderthal ancestor. Nature, 524, 216-219.

Galanidou, N. \& Tzedakis, P. C. (2001). New AMS dates from Upper Palaeolithic Kastritsa. Proceedings of the Prehistoric Society, 67, 271-278.

Gamble, C. (1984). Regional variation in hunter-gatherer strategy in the Upper Pleistocene in Europe. In R. Foley (Ed.), Hominid evolution and community ecology (pp. 237-260). London: Academic Press.

Garate, D. (2013). Altamira and Paleolithic cave art of northern Spain. In C. Smith (Ed.), Encyclopedia of global archaeology (pp. 158-163). New York: Springer.

Gaudzinski, S., \& Jöris, O. (2015). Contextualising the female image: Symbols for common ideas and communal identity in Upper Palaeolithic societies. In F. Coward, R. Osfield, M. Pope, \& F. Wenban-Smith (Eds.), Settlement, society, and cognition in human evolution (pp. 288-314). Cambridge: Cambridge University Press.

González Sainz, C., Ruiz-Redondo, A., Garate Maidagan, D., \& Iriarte Avilés, E. (2013). Not only Chauvet: Dating Aurignacian rock art in Altxerri B Cave (northern Spain). Journal of Human Evolution, 65, 457-464.

Guadelli, A. (2004). Une relecture de l'os gravé de la couche 12 du site Paléolithique de Bacho Kiro (Bulgarie Nord). Archaeologia Bulgarica, 8(2), 1-10.

Guadelli, A. (2005). Réattribution culturelle des artefacts en matière dure animale des couches 12, 11a et 11 du site Paléolithique de Bacho Kiro (Bulgarie Nord). Archaeologia Bulgarica, 9(3), 1-2. 
Hahn, J. (1984). Südeuropa und Nordafrika. In O. Bar-Yosef, G. Corvinus, J. Hahn, H. H. Loofs-Wissowa, H. Müller-Beck, \& A. Ono (Eds.), Neue Forschungen zur Altsteinzeit. Forschungen zur algemeinen und vergleichenden Archäologie 4 (pp. 1-231). Munich: Beck.

Hauck, T., Ruka, R., Gjipali, I., Richter, J., \& Vogels, O. (2016). Recent discoveries of Aurignacian and Epigravettian sites in Albania. Journal of Field Archaeology, 41(2), 148-161.

Higham, T., Basell, L., Jacobi, R., Wood, R., Ramsey, C.B., \& Conard, N.J. (2012). Testing models for the beginnings of the Aurignacian and the advent of figurative art and music: The radiocarbon chronology of Geißenklösterle. Journal of Human Evolution, 62, 664-676.

Hoffecker, J. F. (2009). The spread of modern humans in Europe. Proceedings of the National Academy of Science, 106, 16040-16045.

Hoffecker, J. F. (2011). The Early Upper Paleolithic of Eastern Europe reconsidered. Evolutionary Anthropology, 20, 24-39.

Huyge, D., Aubert, M., Barnard, H., Claes, W., Darnell, J. C., De Dapper, M., Figari, E., Ikram, S., Lebrun-Nélis, A., \& Therasse, I. (2007). Lascaux along the Nile: Late Pleistocene rock art in Egypt. Antiquity, 81(313), 1-6.

Jacobson, E. (2002). Le plus ancien art à l'air libre en Mongolie-Altaï: Image et paléoécologie. In Sacchi, D. (Ed.), L'art paléolithique à l'air libre : Le paysage modifié par l'image (pp. 217-226). Perpignan: GAEP/Géopré.

Janković, I., Komšo, D., Ahern, J. C. M., Becker, R., Gerometta, K., Weinstock, J., Barbir, A., Vukosavljević, N., Cvitkušić, B., Zubcić, K., Mihelić S., \& Smith, F. H. (2017). New research on the Late Pleistocene in the Lim Channel, Istria. Antiquity, 91(359), e4: 1-7.

Janković, I., Vukosavljević, N., Ahern, J. C. M., Karavanić, I., Mihelić, S. \& Smith, F. H. (2018). Bukovac cave revisited: Recent excavations of an Early Upper Paleolithic site in the Gorski kotar region of Croatia. Archäologisches Korrespondenzblatt, 48(3), 297-306.

Kaczanowska, M., Kozłowski, J. K., \& Sobczyk, K. (2010). Upper Palaeolithic human occupations and material culture at Klissoura Cave 1. Eurasian Prehistory, 7(2), 133-285.

Karavanić, I. (2003). L'industrie aurignacienne de la grotte de Šandalja II (Istrie, Croatie) dans le contexte de la région de l'est de l'Adriatique. L'Anthropologie, 107, 577-602.

Karavanić, I. (2017). Paleolitički lovci skupljači na tlu Hrvatske. Zagreb: Matica hrvatska.

Karavanić, I., \& Vukosavljević, N. (2018). Problem of the Middle/Upper Paleolithic interface in the eastern Adriatic. In The origins of the Upper Paleolithic in Eurasia and the evolution of the genus Homo. Proceedings of the International Symposium (Denisova Cave, Altai, Russia, July 2-8, 2018) (pp. 38-47). Novosibirsk: In- 
stitute of Archaeology and Ethnography Siberian branch of the Russian Academy of Sciences.

Komšo, D. (2008). Limski kanal. Hrvatski arheološki godišnjak, 4, 264-268.

Kotjabopoulou, E., \& Adam, E. (2004). People, mobility and ornaments in Upper Palaeolithic Epirus, NW Greece. In M. Otte, (Ed.), La spiritualité (pp. 37-53). Liège: ERAUL 106.

Koumouzelis, M., Ginier, B., Kozlowski, J. K., Pawlikowski, M., Bar-Yosef, O., Albert, R. M., Litynska-Zajic, M., Stronewicz, E., Wojtal, P., Lipecki, G., Tomek, T., Bochenski, Z. M., \& Pazdur, M. (2001). The Early Upper Palaeolithic in Greece: The excavations in Klissoura Cave. Journal of Archaeological Science, 28(13), 515-539.

Kozłowski, J. K. (1999). Gravettian/Epigravettian sequences in the Balkans: Environment, technologies, hunting strategies and raw material procurement. In G. N. Bailey, E. Adam, E. Panagopoulou, C. Perlès, \& K. Zachos, (Ed.), The Paleolithic archaeology of Greece and adjacent areas. Proceedings of the ICOPAG Conference, Ioannina, September 1994. British School at Athens Studies 3 (pp. 319329). Athens: British School at Athens.

Kozłowski, J. K., Laville, H., \& Sirakov, N. (1989). Une nouvelle séquence géologique et archéologique dans les Balkans : La grotte Temnata à Karlukovo (Bulgarie du Nord). L'Anthropologie, 93(1), 159-172.

Kuhn, S. L., \& Stiner, M. C. (2007). Body ornamentation as information technology: Towards an understanding of the significance of early beads. In P. Mellars, K. Boyle, O. Bar-Yosef, \& C. Stringer (Eds.), Rethinking the human revolution: New behavioural and biological perspectives on the origin and dispersal of modern humans (pp. 45-54). Cambridge: McDonald Institute for Archaeological Research.

Kuhn, S. L., \& Zwyns, N. (2014). Rethinking the initial Upper Paleolithic. Quaternary International, 347, 29-38.

Kuhn, S. L., Stiner, M.C., \& Güleç, E. (1999). Initial Upper Palaeolithic in south-central Turkey and its regional context: A preliminary report. Antiquity, 73, 505-517.

Kuhn, S., Mihailović, D., \& Dimitrijević, V. (2014). The Southeast Serbia Paleolithic Project: An interim report. In D. Mihailović (Ed.), Palaeolithic and Mesolithic research in central Balkans (pp. 97-106). Belgrade: Serbian Archaeological Society.

Kuhn, S. L., Stiner, M. C., Reese, D. S., \& Güleç, E. (2001). Ornaments in the earliest Upper Paleolithic: New results from the Levant. Proceedings of the National Academy of Sciences, 98, 7641-7646.

Kujundžić, Z. (1989). Gravure na stijeni i gravirani ukrasi na upotrebnim predmetima Badanj i Pecina pod lipom. Glasnik Zemaljskog muzeja Bosne i Hercegovine (A) n.s. sv., 44, 2-38.

Leroi-Gourhan, L. (1965). Préhistoire de l'art occidental. Paris: Lucien Mazenod. 
Malez, M. (1979). Nalazišta paleolitskog i mezolitskog doba u Hrvatskoj. In A. Benac (Ed.), Praistorija jugoslavenskih zemalja 1 (pp. 227-276). Sarajevo: Svjetlost.

Malez, M. (1987). Pregled paleolitičkih i mezolitičkih kultura na području Istre. In V. Jurkić, (Ed.), Arheološka istraživanja u Istri i Hrvatskom primorju, Izdanja Hrvatskog arheološkog društva, 11 (pp. 3-47). Zagreb: Hrvatsko arheološko društvo.

Malez, M., \& Vogel, J. C. (1969). Rezultati određivanja apsolutne starosti pleistocenskih naslaga Šandalje II kod Pule u Istri. Geološki vjesnik, 22(1968), 121-133.

Marks, A. E., \& Ferring, C. R. (1988). The Early Upper Palaeolithic of the Levant. In J. E. Hoffecker, \& C. A. Wolf (Eds.), The Early Upper Palaeolithic: Evidence from Europe and the Near East. BAR International Series 437 (pp. 43-72). Oxford: British Archaeological Reports.

Marshack, A. (1982). Non-utilitarian fragment of bone from the Middle Palaeolithic layer. In J. K. Kozłowski (Ed.), Excavation in the Bacho Kiro cave: Final report (pp. 117-118). Krakow: Państwowe Wydawnictwo Naukowa.

McBrearty, S., \& Brooks, A. S. (2000). The revolution that wasn't: A new interpretation of the origin of Modern Human behavior. Journal of Human Evolution, 39(5), 453-563.

Mellars, P. (1989). Major issues in the emergence of Modern Humans. Current Anthropology, 30, 349-385.

Mellars, P. (2005). The impossible coincidence: A single-species model for the origins of Modern Human behavior in Europe. Evolutionary Anthropology, 14, 12-27.

Mihailović, D. (2009). Upper Palaeolithic and Mesolithic chipped stone industries from Crvena Stijena. Belgrade: Faculty of Philosophy in Belgrade, Center for Archaeological Research.

Mihailović, D. (2014). Palaeolithic and Mesolithic research in central Balkans. Belgrade: Serbian Archaeological Society.

Mihailović, D., \& Mihailović, B. (2007). Considérations sur le gravettien et l'épigravettien ancien des Balkans de l'ouest. Paléo, 19(1), 113-128.

Mihailović, D., Mihailović, B., \& Lopičić, M. (2011). The Paleolithic of northern Serbia. In F. Draşovean \& B. Jovanović (Eds.), The prehistory of Banat, vol. I. The Palaeolithic and Mesolithic (pp. 77-101). Bucharest: The Publishing House of the Romanian Academy.

Mihailović, D., \& Mihailović, B. (2014). Population dynamics and cultural changes in the Early Upper Palaeolithic of the central Balkans. In M. Otte, \& B. Le BrunRicalens, (Eds.), Modes de contacts et de déplacements au Paléolithique eurasiatique (pp. 369-382). Luxembourg: Centre National de la Recherche Archéologique. 
Miracle, P. T. (1995). Broad-spectrum adaptations re-examined: Hunter-gatherer responses to Late Glacial environmental changes in the eastern Adriatic. Unpublished PhD thesis. Michigan: The University of Michigan.

Miracle, P. T. (1996). Diversification in Epipaleolithic subsistence strategies along the eastern Adriatic coast: A simulation approach applied to zooarchaeological assemblages. Atti del Museo Civico di Storia Naturale di Trieste, IX, 33-62.

Mithen, S. J. (1996). The prehistory of the mind: A search for the origins of art, religion, and science. London: Thames \& Hudson.

Molodin, V. I., \& Cherimisin, D. V. (2001). Les plus anciens petroglyphs du plateau d'Ukok (Altaï, Russie) et leurs analogies en Asie central et en Europe occidentale. In D. Sacchi, (Ed.), L'art paléolithique à l'air libre : Le paysage modifié par l'image (pp. 227-233). Perpignan: GAEP/Géopré.

Montet-White, A., \& Johnson, A. E. (1976). Kadar: A Late Gravettian site in northern Bosnia, Yugoslavia. Journal of Field Archaeology, 3, 407-424.

Montet-White, A., Laville, H., \& Lezine, A.-M. (1986). Le Paléolithique en Bosnie du Nord: chronologie, environnement et préhistoire. L'Antropologie, 90, 29-88.

Moro Abadía, O., \& González-Morales, M. R. (2003). L'art bourgeois de la fin du XIX'e siècle face à l'art mobilier Paléolithique. L'Anthropologie, 107, 455-470.

Moro Abadía, O., \& González-Morales, M. R. (2004). Towards a genealogy of the concept of 'Paleolithic mobiliary art'. Journal of Anthropological Research, 60(3), 321-339.

Moro Abadía, O., \& Nowell, A. (2015). Palaeolithic personal ornaments: Historical development and epistemological challenges. Journal of Archaeological Method and Theory, 22, 952-979.

Oros Sršen, A., Brajković, D., Radović, S., Mauch Lenardić, J., \& Miracle P. T. (2014). The avifauna of southern Istria (Croatia) during the Late Pleistocene: Implications for the palaeoecology and biodiversity of the northern Adriatic region. International Journal of Osteoarchaeology, 24, 289-299.

Perlès, C. (1987). Les industries lithiques taillées de Franchthi (Argolide, Grèce). Tome I: Presentation général et industries paléolithiques. Excavations at Franchthi Cave, Greece fasc 3. Bloomington: Indiana University Press.

Pettitt, P., Bahn, P., \& Ripoll, S. (2007). Palaeolithic cave art at Creswell Crags in European context. Oxford: Oxford University Press.

Richards, M., Karavanić, I., Pettitt P. B., \& Miracle, P. (2015). Isotope and faunal evidence for high levels of freshwater fish consumption by Late Glacial humans at the Late Upper Palaeolithic site of Šandalja II, Istria, Croatia. Journal of Archaeological Science, 61, 204-212.

Ruiz-Redondo, A. (2014). Seeking for the origins of Paleolithic graphic activity: Archaeological rock art survey in Serbia. In D. Mihailović (Ed.), Palaeolithic and Mesolithic research in central Balkans (pp. 131-138). Belgrade: Serbian Archaeological Society. 
Ruiz-Redondo, A., González-Sainz, C., \& Garate-Maidagan, D. (2017). Back to the past: Symbolism and archaeology in Altxerri B (Gipuzkoa, Northern Spain). Quaternary International, 432, 66-76.

Ruiz-Redondo, A., Komšo, D., Garate, D., Moro-Abadía, O., González-Morales, M. R., Jaubert, J., \& Karavanić, I. (2019). Expanding the horizons of Palaeolithic rock art: the site of Romualdova Pećina (Croatia). Antiquity, 93(368), 297-312.

Ruiz-Redondo, A., Mihailović, D., \& Kuhn, S. L. (2018). First results of rock art survey in Central Balkans: Analysis of the graphic remains of Selačka 3 (Serbia). In H. Floss, \& A. Pastoors (Eds.), Palaeolithic rock and cave art in Central Europe? (pp. 151-159). Rahden: Verlag Marie Leidorf.

Sirakov, N., Guadelli, J. L., Sirakova, S., Tillier, A.-M., Taneva, S., Miteva, V., Guadelli, A., Krumov, I., Dimitrova, I., Nikolov, P., Spasov, R., \& Pusheva, P. (2014). Terenni prouchvaniya na paleolita u peştera Kozarnika, obştina Dimovo. Arkheologicheski Otkritiya i Razkopki, 2014, 27-29.

Srdoč, D., Sliepčević, A., Planinić, J., Obelić, B., \& Breyer, B. (1973). Rudjer Bošković radiocarbon measurements II. Radiocarbon, 15(2), 435-441.

Straus, L. G. (1996). Continuity or rupture; convergence or invasion; adaptation or catastrophe; mosaic or monolith: Views on the Middle to Upper Paleolithic transition in Iberia. In E. Carbonell, \& M. Vaquero, (Eds.), The last Neandertals, the first Anatomically Modern Humans (pp. 203-218). Tarragona: Universidad Rovira i Virgili.

Svoboda, J. (1995). L'art gravettien en Moravie: Contexte, dates et styles. L'Anthropologie, 99, 258-272.

Svoboda, J. (2007). Upper Palaeolithic anthropomorph images of northern Eurasia. In C. Renfrew, and I. Morley (Eds.), Image and imagination: A global prehistory of figurative representation (pp. 65-76). Cambridge: McDonald Institute for Archaeological Research.

Tsanova, Ts. (2003). Le Gravettien en Bulgarie du Nord : Niveau IVb de la grotte Kozarnika. In T. Tsonev, \& K. Montagnari (Eds.), The humanized mineral world: Towards social and symbolic evaluation of prehistoric technology in South Eastern Europe (pp. 33-39). Liège: ERAUL 103.

Tsanova, Ts. (2008). Les débuts du Paléolithique supérieur dans l'Est des Balkans : Réflexion à partir de l'étude taphonomique et techno-économique des ensembles lithiques des sites de Bacho Kiro (couche 11), Temnata (couches VI et 4) et Kozarnika (niveau VII). BAR International Series 1752. Oxford: Archaeopress.

Tsanova, Ts. (2009). Contribution méthodologique concernant la séquence archéologique du début du Paléolithique Supérieur à Temnata (Bulgarie du Nord): Approche taphonomique des ensembles lithiques dans leur intérêt stratigraphique. In I. Gatsov \& J.-L. Guadelli (Ed.), Saxa loquuntur: In honor of 65 anniversary of Nikolay Sirakov (pp. 145-169). Sofia: Avalon. 
Tsanova, Ts., Zwyns, N., Eizenberg, L., Teyssandier, N., Le Brun-Ricalens, F., \& Otte, M. (2012). Le plus petit dénominateur commun : Réflexion sur la variabilité des ensembles lamellaires du Paléolithique supérieur ancien d'Eurasie. Un bilan autour des exemples de Kozarnika (Est des Balkans) et Yafteh (Zagros central). L'Anthropologie, 116, 469-509.

Ucelli Gnesutta, P., \& Cristiani, E. (2002). Analisi stilistica e tecnologica di frammenti di osso decorato dai livelli epigravettiani della Grotta di Settecannelle (Viterbo). Rivista di Scienze Preistoriche, 52, 143-160.

Vanhaeren, M., \& d'Errico, F. (2005). Aurignacian ethno-linguistic geography of Europe revealed by personal ornaments. Journal of Archaeological Science,33, 1105-1128.

Villaverde Bonilla, V. (1994). Arte paleolítico de la Cova de Parpalló: Estudio de la colección de plaquetas y cantos grabados y pintados. Valencia: Servei d'Investigació Prehistòrica de la Diputació de València.

Vujević, D., \& Parica, M. (2010). Nakit i umjetnost Pećine Vlakno. Archaeologia Adriatica, 3, 23-34.

Vujević, D. (2018). Pećina Vlakno na Dugom otoku. Subterranea Croatica, 25, 41-46.

Vukosavljević, N., \& Karavanić, I. (2017). Epigravettian shouldered points in the eastern Adriatic and its hinterland: Reconsidering their chronological position. Acta Archaeologica Carpathica, 52(2017), 5-21.

Whallon, R. (1989). The Paleolithic site of Badanj: Recent excavations and results of analysis. Glasnik Zemaljskog muzeja Bosne i Hercegovine, (A), n.s. sv. , 44, 7-20.

Whallon, R. (1999). The lithic tool assemblages at Badanj within their regional context. In G. N. Bailey, E. Adam, E. Panagopoulou, C. Perlès, \& K. Zachos (Ed.), The Paleolithic archaeology of Greece and adjacent areas. Proceedings of the ICOPAG Conference, Ioannina, September 1994. British School at Athens Studies 3 (pp. 330-342). Athens: British School at Athens.

Zilhão, J. (2007). The emergence of ornaments and art: An archaeological perspective on the origins of 'behavioral modernity'. Journal of Archaeological Research, 15, 1-54. 